\title{
Synthesis and Characterization of the Novel Thiophene Derivatives
}

\author{
Adnan CETIN $^{1^{*}} \quad$ Havva KURT $^{2} \quad$ Sedat BOZARI $^{2}$
}

\begin{abstract}
The use of thiophene derivatives that have a stable structure in agriculture, food and pharmaceutical industries has revealed the necessity of synthesizing different derivatives. For this purpose, in the current study, some substituted thiophene derivatives have been designed and synthesized. The characterization of the synthesized compounds was determined by spectroscopic methods. The possible antimicrobial activities of these compounds (3-9, 10a-e, 11-13) were measured by disc diffusion method against gram positive (Bacillus subtilis ATCC 6633, Staphylococcus aureus 6538) and gram negative (Enterobacter aerogenes ATCC 13048, Escherichia coli) bacteria. The synthesized substituted thiophene compounds do not showed any antibacterial activities against test bacteria.
\end{abstract}

Keywards: Heterocyclic compounds, hydrazide, thiophene, oxadiazole, pyrazole

\section{Yeni Tiofen Türevlerin Sentezlenmesi ve Karakterizasyonu}

ÖZET: Kararlı bir yapıya sahip tiyofen türevlerinin ziraat, gıda ve ilaç sanayilerinde kullanımı farklı türevlerinin sentezlenmesi gerekliliğini ortaya koymuştur. Bu amaçla, mevcut çalışmada bazı substitüe tiofen türevleri tasarlanıp sentezlendi. Sentezlenen bileşiklerin karakterizasyonu, spektroskopik yöntemlerle belirlendi. Bu bileşiklerin (3-9, 10a-e, 11-13) olası antimikrobiyal aktiviteleri gram pozitif (Bacillus subtilis ATCC 6633, Staphylococcus aureus 6538) ve gram negatif (Enterobacter aerogenes ATCC 13048, Escherichia coli) bakterilere karşı disk difüzyon metodu ile ölçüldü. Sentezlenen substitüe tiofen bileşiklerinin test bakterilerine karşı herhangi bir aktivite göstermediği belirlendi.

Anahtar Kelimeler: Heterosiklik bileşikler, hidrazid, tiofen, okzadiazol, pirazol

\footnotetext{
${ }^{1}$ Adnan CETIN (Orcid ID: 0000-0002-2951-1934), Muş Alparslan Üniversitesi, Eğitim Fakültesi, Matematik ve Fen Bilimleri Eğitimi Bölümü, Muş, Türkiye

${ }^{2}$ Havva KURT (Orcid ID: 0000-0002-2951-1934), Sedat BOZARI (Orcid ID: 0000-0001-5265-2236), Muş Alparslan Üniversitesi, Fen Edebiyat Fakültesi, Moleküler Biyoloji Bölümü, Muş, Türkiye

*Sorumlu Yazar/Corrensponding Author: Adnan CETIN, e-mail: a.cetin@alparslan.edu.tr 


\section{INTRODUCTION}

Heterocyclic compounds are important compounds in the organic chemistry because of their significant properties in the various areas such as medicinal, food and agricultural industries (Fakhr et al., 2009; Gouda et al., 2010). Thiophene is a five-membered aromatic ring structure in the heterocyclic chemistry. It contains one sulfur atom as a heteroatom and four carbon atoms. Thiophene can extremely behave reactive like benzene in terms of having a pie electron cloud structure. The substituted thiophene derivatives are very well known for medicinal applications. Many substituted thiophene compounds have performed as chemotherapeutic and anticancer agents. For these reasons, substituted thiophene compounds were also applied successfully in other fields such as pharmacology, agriculture and industrial applications. These compounds were used in the development of agricultural products and in drug research since they have diverse biological activities. Some known activities are antitubercular, analgesic, anti-inflammatory, anti-metabolite, anti-bacterial, antifungal, and antineoplastic (William, 1989; Moghaddam and Boinee, 2004; Parai et al., 2008; Pinto et al., 2008; Zarudnitskii et al., 2008; Isloor et al., 2010; Sagardoy et al., 2010; Andersson et al., 2012). Hence, they are popular targets for organic chemists. These compounds have been studied for a long time and still continue to attract considerable attention in literature. Some of the drugs that have substituted thiophene derives are showed in Figure 1.

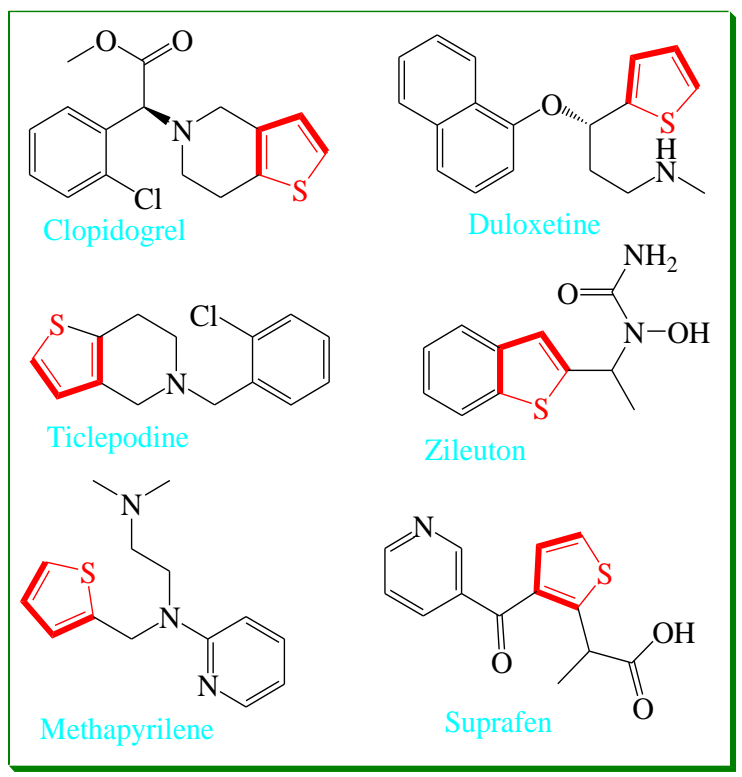

Figure 1. Some of the important examples of substituted thiophenes

The cyclocondensation reactions of $\alpha, \beta$ unsaturated carbonyl compounds have used widely to preparation of substituted thiophenes. Moreover, the various methods for the synthesis of substituted triazole and oxadiazole compounds were reported in literature (Zhang et al., 2002; Ramazani and Rezaei, 2010). They have also brought out significant pharmacological and biological activities
(Naresh et al., 2013; Patel et al., 2013). The structures having substitute 1,2,4-triazoles and 1,3,4-oxadiazoles were performed in many different studies (Christophe et al., 2011; Maddila et al., 2013). Previous studies have reported that these compounds are important goals of the molecules in the field of synthetic and medicinal chemistry. Aim of the present study was to synthesize substituted thiophene 
compounds, their characterization and investigating their possible antibacterial activities.

\section{MATERIAL AND METHODS}

\section{General}

All chemical materials were available commercially from Sigma and Merck companies. Melting points of synthesized compounds were performed on an Electrothermal Scientific Flash 2000. Shimadzu IR-470 spectrophotometer is used to measure the infrared spectra of synthesized compounds. ${ }^{1} \mathrm{H}$ (400 MHz) and ${ }^{13} \mathrm{C}(100 \mathrm{MHz})$ NMR spectra were recorded on a Bruker DRX-400 high performance digital FT-NMR spectrometer. Elemental analyses were carried out on Thermo Scientific Flash 2000. The mass spectrum was measured on Agilent 5973 Mass Spectrometer.

\section{Synthesis of $N$-(4-phenyl-2-thioxothiazol-}

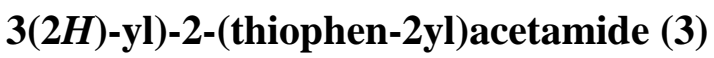

Potassium thiocarbazinate $2(0.5 \mathrm{mmol}, 0.143$ g) was added to ethanol $(10 \mathrm{ml})$. The phenyl bromide $(0.5 \mathrm{mmol}, 0.199 \mathrm{~g})$ was added to prepared solution. The mixture was refluxed for $3 \mathrm{~h}$. Then, reaction process was allowed to room temperature. The precipitated solid was filtered. It was washed with ethanol. The product was dried. It was crystallized from ethanol. Yield (0.23 g, 67\%); M.p: $206-208{ }^{\circ} \mathrm{C}$; IR $\left(v, \mathrm{~cm}^{-1}\right)$ : 3142, 3065, 1680, 1498-1442. ${ }^{1}$ H-NMR (400 $\left.\mathrm{MHz} \mathrm{CDCl}_{3}\right) \delta$ (ppm): 9.05 (s, 1H), 7.28-6.52 (m, 10H, aromatic), 3.45 (s, 2H). ${ }^{13} \mathrm{C}-\mathrm{NMR}$ (100 $\left.\mathrm{MHz}, \mathrm{CDCl}_{3}\right) \delta$ (ppm): 189.47, 167.26, 154.63, $132.09,130.71,130.12,129.65,129.0,128.46$, $128.12,125.15,124.35,123.18,110.68,36.25$. ESI MS (M+H)+: 333.1 .

\section{Synthesis of ethyl 2-(5-(thiophen-2ylmethyl)- 1,3,4-oxadiazol-2-ylthio)acetate (4)}

2 (0.5 mmol, $0.143 \mathrm{~g})$ was dissolved to ethanol $(10 \mathrm{ml})$. The ethyl-2-bromoacetate $(0.5$ mmol, $0.167 \mathrm{~g}$ ) was added to prepared solution.
The mixture was refluxed for 3 hours. The reaction was allowed to room temperature. The precipitated solid was filtered. It was washed with ethanol. The product was dried. It was crystallized from ethanol. Yield (0.12 g, 39\%); M.p: $248{ }^{\circ} \mathrm{C}$; IR $\left(v, \mathrm{~cm}^{-1}\right)$ : 3080, 2925, 1721, 1497-1444. ${ }^{1} \mathrm{H}-\mathrm{NMR} \quad\left(400 \mathrm{MHz}, \mathrm{CDCl}_{3}\right) \quad \delta$ (ppm): 6.95-6.55 (m, 3H, aromatic), $4.01(\mathrm{~m}$, $2 \mathrm{H}), 3.76(\mathrm{~m}, 2 \mathrm{H}), 3.32(\mathrm{~m}, 2 \mathrm{H}), 1.24(\mathrm{~m}, 3 \mathrm{H})$. ${ }^{13} \mathrm{C}-\mathrm{NMR}\left(100 \mathrm{MHz}, \mathrm{CDCl}_{3}\right) \delta$ (ppm): 166.36, $151.15,139.09,131.35,126.55,123.33,120.42$, 57.53, 38.25, 26.17, 14.20. ESI MS $(\mathrm{M}+\mathrm{H})+$ : 285.0 .

Synthesis of 4-phenyl-1-(2-(thiophen-2yl) acetyl) thiosemicarbezide (5)

2-(thiophen-2yl)acetohydrazide $1(0.5 \mathrm{mmol}$, $0.156 \mathrm{~g})$ and phenyl isothiocyanate $(1 \mathrm{mmol}$, $0.135 \mathrm{~g})$ were refluxed in dry benzene $(15 \mathrm{ml})$ for $5 \mathrm{~h}$. The process was allowed to room temperature. The precipitated solid was filtered. It was washed with ethanol. The product was dried. It was crystallized from ethanol. Yield (0.15 g, 52\%); M.p: $211{ }^{\circ} \mathrm{C}$; IR ( $\left.v, \mathrm{~cm}^{-1}\right)$ : 3235, 3210, 3065, 2890, 1682, 1671, 1502-1432. ${ }^{1} \mathrm{H}-$ NMR (400 MHz, $\left.\mathrm{CDCl}_{3}\right) \delta(\mathrm{ppm}): 9.37$ (d, $J=$ 9.6, $1 \mathrm{H}), 7.20-6.54(\mathrm{~m}, 8 \mathrm{H}$, aromatic), $4.15(\mathrm{~s}$, $1 \mathrm{H}), 3.36(\mathrm{~s}, 2 \mathrm{H}), 1.96(\mathrm{~d}, J=5.8,1 \mathrm{H}) .{ }^{13} \mathrm{C}-\mathrm{NMR}$ $\left(100 \mathrm{MHz}, \mathrm{CDCl}_{3}\right) \delta$ (ppm): 178.39, 167.57, 135.47, 133.22, 131.56, 130.23, 129.74, 129.12, $128.43,127.67,126.05,119.26,30.25$. ESI MS $(\mathrm{M}+\mathrm{H})+: 292.3$.

\section{Synthesis of 4-phenyl-5-(thiophen-2ylmethyl)-} 4H-1,2,4-triazole-3-thiol (6)

5 (1 mmol, $0.291 \mathrm{~g})$ was refluxed in potassium hydroxide solution $(5 \mathrm{ml})$ for $4 \mathrm{~h}$. After the reaction mixture was filtered hot. It was kept overnight at room temperature. Precipitated solid was washed with water, filtered and the obtained product was dried. It was crystallized with ethanol. Yield $(0.16 \mathrm{~g}$, 55\%); M.p: $244-246{ }^{\circ} \mathrm{C}$; IR $\left(v, \mathrm{~cm}^{-1}\right): 3065$, 2885，2668，1620，1498-1442. ${ }^{1}$ H-NMR (400 
$\left.\mathrm{MHz}, \mathrm{CDCl}_{3}\right) \delta(\mathrm{ppm}): 12.10$ (s, 1H). 7.15-6.60 (m, 8H, aromatic), 3.35 (s, 2H). ${ }^{13} \mathrm{C}-\mathrm{NMR}$ (100 $\left.\mathrm{MHz}, \mathrm{CDCl}_{3}\right) \delta(\mathrm{ppm}): 170.55,165.37,140.69$, $132.15,131.16,130.72,129.54,128.40,127.97$, 127.85, 126.94, 123.10, 26.49. ESI MS (M+H)+: 274.0 .

\section{Synthesis of N-phenyl-5-(thiophen-} 2ylmethyl)-1,3,4-oxadiazol-2-amine (7)

3 ( $1 \mathrm{mmol}, 0.291 \mathrm{~g})$ was added in ethanol (2.5 $\mathrm{ml})$. The sodium hydroxide solution $(1 \mathrm{ml})$ was added prepared solution. Solutions of iodine and potassium iodide were added drop wise with stirring till color of iodine persisted. The obtained mixture was heated in the water bath for 5 hours. The mixture was allowed to room temperature. The obtained product was filtered. After it was dried, it was crystallized with ethanol. Yield (0.098 g, 34\%); M.p: $231{ }^{\circ} \mathrm{C}$; IR $\left(v, \mathrm{~cm}^{-1}\right): 3235,3080,2875,1610,1498-1443$. ${ }^{1} \mathrm{H}-\mathrm{NMR}\left(400 \mathrm{MHz}, \mathrm{CDCl}_{3}\right.$ ) $\delta$ (ppm): 7.10-6.38 (m, 8H, aromatic), $3.89(\mathrm{~s}, 1 \mathrm{H}), 3.36(\mathrm{~s}, 2 \mathrm{H})$. ${ }^{13} \mathrm{C}-\mathrm{NMR}\left(100 \mathrm{MHz}, \mathrm{CDCl}_{3}\right) \delta$ (ppm): 164.72, 157.24, 142.63, 139.57, 131. 52, 130.24, 129.62, 129.10, 128.63, 127.16, 124.07, 119.63, 28.57. ESI MS $(\mathrm{M}+\mathrm{H})+:$ 258.3.

\section{Synthesis of 1-(5-amino-3-hydroxy- $1 H$ -} pyrazol-1-yl)-3-(thiophen-2yl)propan-2-one (8)

1 (1 mmol, $0.156 \mathrm{~g})$ was dissolved in potassium hydroxide (10\% $5 \mathrm{ml})$. The dissolved ethylcyano acetate $(1 \mathrm{mmol}, 0.099 \mathrm{~g})$ in ethanol $(10 \mathrm{ml})$ was added prepared solution. The mixture was refluxed for $10 \mathrm{~h}$. The process was allowed to room temperature. The mixture was diluted with water. It was acidified by concentrate hydrochloric acid. The precipitated solid was filtered. It was washed with water. After it was dried, It was crystallized by $N, N$ dimethylformamide: ethanol (1:1). Yield $(0.07 \mathrm{~g}$, 28\%); M.p: $284-286{ }^{\circ} \mathrm{C}$; IR $\left(v, \mathrm{~cm}^{-1}\right)$ : 3415, 3158, 3080, 2865, 1665, 1498-1444. ${ }^{1} \mathrm{H}-\mathrm{NMR}$ (400 MHz, $\left.\mathrm{CDCl}_{3}\right) \delta(\mathrm{ppm})$ : 7.26-6.70 (m, 4H, aromatic), $5.36(\mathrm{~s}, 1 \mathrm{H}), 3.86(\mathrm{~s}, 2 \mathrm{H}), 3.34(\mathrm{~s}$, 2H), 2.48 (s, 2H). ${ }^{13} \mathrm{C}-\mathrm{NMR}\left(100 \mathrm{MHz}, \mathrm{CDCl}_{3}\right)$ $\delta$ (ppm): 193.07, 147.12, 144.10, 130.26, 129.50, 128.18, 126.27, 122.47, 46.74, 25.49. ESI MS $(\mathrm{M}+\mathrm{H})+:$ 238.1.

\section{Synthesis of 2-phenyl-5-(thiophen-2ylmethyl)- 1,3,4-oxadiazole (9)}

1 (1 mmol, $0.156 \mathrm{~g})$ and benzoic acid (1 mmol, $0.122 \mathrm{~g}$ ) were added in trifluoroacetic acid $(5 \mathrm{ml})$. The mixture was heated for $6 \mathrm{~h}$. The process was allowed to room temperature. The crushed ice was added and kept overnight. The precipitated solid was neutralized with sodium bicarbonate. It was washed with water and filtered. It was crystallized from ethanol. Yield (0.1 g, 36\%); M.p: >300 ${ }^{\circ} \mathrm{C}$; IR (v, $\left.\mathrm{cm}^{-1}\right): 3080$, 2865, 1670, 1498-1442. ${ }^{1} \mathrm{H}-\mathrm{NMR}$ (400 MHz, $\left.\mathrm{CDCl}_{3}\right) \delta$ (ppm): 7.37- 6.39 (m, 8H, aromatic), 3.35 (s, 2H). ${ }^{13} \mathrm{C}-\mathrm{NMR}\left(100 \mathrm{MHz}, \mathrm{CDCl}_{3}\right) \delta$ (ppm): 162.14, 158.69, 135.06, 132.45, 130.10, 129, 56, 129.12, 128,94, 128.16, 127.62, 126,38, 121.31, 28.41. ESI MS (M+H)+: 243.1.

\section{Synthesis of $N$-(substituted benzylidine)-2- (thiophen-2yl)acetohydrazide (10a-e)}

$1(0.5 \mathrm{mmol}, 0.078 \mathrm{~g})$ and various aromatic aldehydes (benzaldehyde, 2-hydroxy benzaldehyde, 2-hydroxy, 5-nitro benzaldehyde, thiophene-2-carbaldehyde, 4-trimethyl amino benzaldehyde, respectively) $(0.5 \mathrm{mmol})$ were refluxed with a few drops glacial acid in ethanol $(10 \mathrm{ml})$ for 4 hours. The mixture was allowed to room temperature. Then cold water was added. The obtained precipitate solid filtered and it was crystallized from ethanol.

\section{Synthesis of $N$-benzylidine-2-(thiophen-2yl)} acetohydrazide (10a)

10a was prepared according to general procedure. Yield (0.08 g, 61\%); M.p: 214-216 ${ }^{\circ} \mathrm{C}$; IR $\left(v, \mathrm{~cm}^{-1}\right): 3210(-\mathrm{NH}), 3080,2870,1680$, 1668, 1562, 1498-1442. ${ }^{1} \mathrm{H}-\mathrm{NMR}(400 \mathrm{MHz}$, $\left.\mathrm{CDCl}_{3}\right) \delta(\mathrm{ppm}): 8.30(\mathrm{~s}, 1 \mathrm{H}), 8.05(\mathrm{~s}, 1 \mathrm{H}), 7.85-$ 
$6.95\left(\mathrm{~m}, 8 \mathrm{H}\right.$, aromatic), $2.98(\mathrm{~s}, 2 \mathrm{H}) .{ }^{13} \mathrm{C}-\mathrm{NMR}$ $\left(100 \mathrm{MHz}, \mathrm{CDCl}_{3}\right) \delta$ (ppm): 169.87, 145.34, 135.66, 131.24, 130.28, 129.36, 129.04, 128.65, 127.23, 124.60, 122.83, 116.72, 35.68. Anal. Calcd. For $\mathrm{C}_{13} \mathrm{H}_{12} \mathrm{~N}_{2} \mathrm{OS}$ : C, 63.91; H, 4.96; N, 11.46. Found: C, 63.96; H, 5.00; N, 11.42 .

\section{Synthesis of $N$-(2-hydroxybenzylidine)-2-} (thiophen-2yl) acetohydrazide (10b)

$10 \mathrm{~b}$ was prepared according to general procedure. Yield (0.08 g, 57\%); M.p: $230-232$ ${ }^{\circ} \mathrm{C}$; IR $\left(v, \mathrm{~cm}^{-1}\right): 3345,3237,3086,2875,1675$, 1664, 1576, 1496-1442. ${ }^{1} \mathrm{H}-\mathrm{NMR}$ (400 MHz, $\left.\mathrm{CDCl}_{3}\right) \delta(\mathrm{ppm}): 8.26(\mathrm{~s}, 1 \mathrm{H}), 7.93(\mathrm{~s}, 1 \mathrm{H}), 7.82-$ $6.83(\mathrm{~m}, 7 \mathrm{H}), 5.49(\mathrm{~s}, 1 \mathrm{H}), 4.18(\mathrm{~s}, 2 \mathrm{H}) .{ }^{13} \mathrm{C}-$ NMR $\left(100 \mathrm{MHz}, \mathrm{CDCl}_{3}\right) \delta$ (ppm): 170.15, $159.65,142.37,135.28,131.02,130.62,129.54$, 128.14, 127.35, 125.72, 123.68, 121.93, 43.37. Anal. Calcd. For $\mathrm{C}_{13} \mathrm{H}_{12} \mathrm{~N}_{2} \mathrm{O}_{2} \mathrm{~S}: \mathrm{C}, 59.98 ; \mathrm{H}$, 4.65; N, 10.76. Found: C, 60.01; H, 4.69; N, 10.79 .

\section{Synthesis of $\quad N^{\prime}-(2-$ hydroxy-5- nitrobenzylidine)-2-(thiophen-2- yl)acetohydrazide (10c)}

Compound 10c was prepared according to general procedure. Yield (0.07 g, 44\%); M.p: 260-263 ${ }^{\circ} \mathrm{C}$; IR $\left(\mathrm{v}, \mathrm{cm}^{-1}\right): 3245,3084,2870$, 1676, 1662, 1570, 1498-1442. ${ }^{1} \mathrm{H}-\mathrm{NMR}(400$ $\left.\mathrm{MHz}, \mathrm{CDCl}_{3}\right) \delta(\mathrm{ppm}): 8.30(\mathrm{~s}, 1 \mathrm{H}), 7.96(\mathrm{~s}$, $1 \mathrm{H})$, 7.74-6.75 (m, 6H, aromatic), $5.75(\mathrm{~s}, 1 \mathrm{H})$, 4.32 (s, 2H). ${ }^{13} \mathrm{C}-\mathrm{NMR}\left(100 \mathrm{MHz}, \mathrm{CDCl}_{3}\right) \delta$ (ppm): 177.42, 169.20, 149.20, 146.38, 138.08, 135.24, 133.49, 130.52, 129. 42, 128.73, 124.28, 118.06, 34.64. Anal. Calcd. For $\mathrm{C}_{13} \mathrm{H}_{11} \mathrm{~N}_{3} \mathrm{O}_{4} \mathrm{~S}$ : C, 51.14; H, 3.63; N, 13.76. Found: C, 51.23; H, $3.58 ; \mathrm{N}, 13.79$.

\section{Synthesis of 2-(tiophene-2-yl)- $N$ '-(thiophen-2- ylmethylene)acetohydrazide (10d)}

Compound 10d was prepared according to general procedure. Yield $(0.05$ g, 37\%); m.p 242-245 ${ }^{\circ} \mathrm{C}$; IR $\left(v, \mathrm{~cm}^{-1}\right): 3218,3086,2874$, 1682, 1656, 1579, 1498-1444. ${ }^{1}$ H-NMR (400
$\left.\mathrm{MHz}, \mathrm{CDCl}_{3}\right) \delta(\mathrm{ppm}): 8.20(\mathrm{~s}, 1 \mathrm{H}), 8.02,(\mathrm{~s}$, $1 \mathrm{H}), 7.58-6.62(\mathrm{~m}, 6 \mathrm{H}$, aromatic), $3.91(\mathrm{~s}, 2 \mathrm{H})$. ${ }^{13} \mathrm{C}-\mathrm{NMR}\left(100 \mathrm{MHz}, \mathrm{CDCl}_{3}\right) \delta$ (ppm): 169.02, 145.67, 139.58, 136.62, 134.13, 130. 36, 129.61, 126.34, 122.87, 119.03, 36.43. Anal. Calcd. For $\mathrm{C}_{11} \mathrm{H}_{10} \mathrm{~N}_{2} \mathrm{OS}_{2}$ : C, 52.78; H, 4.03; N, 11.19. Found: C, 52.79; H, 4.04; N, 11.15.

Synthesis of N'-(4(dimethylamino)benzylidine)-2-(thiophen-2yl) acetohydrazide (10e)

Compound 10e was prepared according to general procedure. Yield (0.08 g, 52\%); M.p: 219-221 ${ }^{\circ} \mathrm{C}$; IR $\left(v, \mathrm{~cm}^{-1}\right): 3241,3084,2869$, 1678, 1667, 1552, 1498-1442. ${ }^{1}$ H-NMR (400 $\left.\mathrm{MHz}, \mathrm{CDCl}_{3}\right) \delta(\mathrm{ppm}): 8.34(\mathrm{~s}, 1 \mathrm{H}), 7.96(\mathrm{~s}$, $1 \mathrm{H}), 7.17-6.61(\mathrm{~m}, 7 \mathrm{H}$, aromatic), $3.56(\mathrm{~s}, 2 \mathrm{H})$, $2.69(\mathrm{~s}, 6 \mathrm{H}) \cdot{ }^{13} \mathrm{C}-\mathrm{NMR}\left(100 \mathrm{MHz}, \mathrm{CDCl}_{3}\right) \delta$ (ppm): 170.17, 147.23, 140.16, 137.28, 134.63, $132.58,130.13,129.51,128.25,127.57,125.06$, 123.63, 39.18, 32.70. Anal. Calcd. For $\mathrm{C}_{15} \mathrm{H}_{17} \mathrm{~N}_{3} \mathrm{OS}$ : C, 62.69; H, 5.96; N, 14.62 . Found: C, 62.73; H, 5.95; N, 14.56.

Synthesis of 3-oxo-3-phenyl- $N$-(2-(thiophen-2yl)acetyl) propanehydrazide (11)

Compound 1 ( $1 \mathrm{mmol}, 0.156 \mathrm{~g}$ ) was added in ethyl acetoacetate $(5 \mathrm{ml})$. The solution was refluxed for $5 \mathrm{~h}$. The mixture was allowed to room temperature. The mixture was diluted with petrol ether. The precipitated solid was filtered. It was washed by water. The obtained product was crystallized from ethanol. Yield $(0.15 \mathrm{~g}$, 44\%); M.p: $291-293{ }^{\circ} \mathrm{C}$; IR $\left(v, \mathrm{~cm}^{-1}\right)$ : 3296 , 3257, 3086, 2874, 1723, 1665, 1654, 1496-1442. ${ }^{1} \mathrm{H}-\mathrm{NMR}$ (400 MHz, $\mathrm{CDCl}_{3}$ ) $\delta$ (ppm): 9.91, 8.70 (m, 2H), 7.90-6.67 (m, 8H, aromatic), 3.51 (s, 2H), 3.15 (s, 2H). ${ }^{13} \mathrm{C}-\mathrm{NMR}\left(100 \mathrm{MHz}, \mathrm{CDCl}_{3}\right)$ $\delta$ (ppm): 191.38, 164.24, 158.08, 136.71, 132.88, 130.42, 130.04, 129.56, 128.86, 128.77, 127.41, 126.06, 124.56, 38.54, 33.09. ESI MS $(\mathrm{M}+\mathrm{H})+$ : 303.2 . 
Synthesis of 3-phenyl-1-(2-(thiophen2yl)acetyl)-1,2-dihydropyrazol-5-one (12)

Compound 11 (0.43 mmol, $0.13 \mathrm{~g}$ ) was added in the potassium hydroxide solution (2 M, 10 $\mathrm{ml})$. The solution was refluxed for 5 hours. The mixture was allowed to room temperature. The mixture was acidified by concentrate hydrochloric acid. The precipitated solid was filtered and washed with water. The obtained product was crystallized by ethanol. Yield $(0.05$ g, 39\%); M.p: $>300{ }^{\circ} \mathrm{C}$; IR (v, $\left.\mathrm{cm}^{-1}\right): 3254,3080$, 2865, 1678, 1497-1442. ${ }^{1} \mathrm{H}-\mathrm{NMR}(400 \mathrm{MHz}$, $\left.\mathrm{CDCl}_{3}\right) \delta(\mathrm{ppm}): 8.10-6.75(\mathrm{~m}, 8 \mathrm{H}), 5.35(\mathrm{~s}$, $1 \mathrm{H}), 3.37(\mathrm{~s}, 2 \mathrm{H}), 2.25(\mathrm{~s}, 1 \mathrm{H}) .{ }^{13} \mathrm{C}-\mathrm{NMR}(100$ $\left.\mathrm{MHz}, \mathrm{CDCl}_{3}\right) \delta$ (ppm): 171.35, 164.39, 158.52, 139.46, 136.90, 135.70, 133.20, 130.42, 129.64, $128.93,127.81,126.12,123.55,112.56,34.45$. ESI MS (M+H)+: 285.0.

\section{Synthesis of 1-(3,5-diphenyl-1H-pyrazol-1-yl)- 3-(thiophen-2yl)propan-2-one (13)}

Compound 1 (1 mmol, $0.156 \mathrm{~g}$ ) and 1,3diphenylpropane-1,3-dione (1 mmol, $0.224 \mathrm{~g}$ ) were added in a few drops $N, N$ dimethylformamide and glacial acid $(5 \mathrm{ml})$. The reaction was mixed at room temperature for 12 h. The mixture was diluted by water. The precipitated solid was filtered and dried. It was crystallized from $N, N$-dimethylformamide: ethanol (1:10). Yield (0.29 g, 78\%); M.p: 225 $227{ }^{\circ} \mathrm{C}$; IR $\left(v, \mathrm{~cm}^{-1}\right): 3080,2857,1648,1598$, 1497-1442. ${ }^{1} \mathrm{H}-\mathrm{NMR} \quad\left(400 \mathrm{MHz}, \mathrm{CDCl}_{3}\right) \quad \delta$ (ppm): 7.96-6.50 (m, 14H), $5.57(\mathrm{~s}, 2 \mathrm{H}), 4.26$ (s, $2 \mathrm{H}) .{ }^{13} \mathrm{C}-\mathrm{NMR}\left(100 \mathrm{MHz}, \mathrm{CDCl}_{3}\right) \delta$ (ppm): 183.41, 145.74, 142.42, 134.03, 131. 26, 130.90, $130.15,129.84,129.12,129.02,128.42,128.13$, $127.58,127.16,126.08,126.63,125.85,124.77$,
121.76, 117.95, 62.10, 46.35. ESI MS $(\mathrm{M}+\mathrm{H})+$ : 359.2 .

\section{RESULTS AND DISCUSSION}

2-(thiophen-2yl)acetohydrazide (1) was purchased commercially. It was used as starting material. Firstly, the potassium thiocarbazinate (2) was prepared according the literature (Meltzer et al., 1953). The potassium thiocarbazinate (2) was obtained from reaction 2-(thiophen-2yl)acetohydrazide (1), carbon disulfide and potassium hydroxide in ethanol. $\mathrm{N}$ (4-phenyl-2-thioxothiazol-3(2H)-yl)-2-

(thiophen-2yl)acetamide (3) and ethyl 2-(5(thiophen-2ylmethyl)-1,3,4- oxadiazol-2ylthio)acetate (4) were synthesized from potassium thiocarbazinate (2) and 2bromoacetophenone or ethyl 2-bromoacetate in boiling ethanol in Scheme 1.

The IR spectrum of compound 3 showed $3142 \mathrm{~cm}^{-1}$ corresponding - $\mathrm{NH}$ amide and 1680 $\mathrm{cm}^{-1}$ carbonyl group absorption bands. The ${ }^{1} \mathrm{H}$ NMR spectrum revealed $\delta 9.0 \mathrm{ppm}$ signal (-NH) proton of amide in the region. The ${ }^{13} \mathrm{C}$ NMR spectrum revealed $189.4 \mathrm{ppm}$ signal of the thiocarbonyl $(\mathrm{C}=\mathrm{S})$ and $\delta 36.2 \mathrm{ppm}$ signal of methylene carbon in the region. The IR spectrum of 1,3,4-oxadiazol 4 showed $1721 \mathrm{~cm}^{-1}$ ester carbonyl group absorption band. The ${ }^{1} \mathrm{H}-\mathrm{NMR}$ spectrums revealed $\delta 3.9,3.5$ and $3.3 \mathrm{ppm}$ signals protons of methylene in the region and $\delta$ $1.2 \mathrm{ppm}$ signals protons of methyl in the region. The ${ }^{13} \mathrm{C}$ NMR spectrum revealed $\delta 166.3 \mathrm{ppm}$ signal of ester carbonyl and $\delta 151.1 \mathrm{ppm}$ signal carbon of (C5) in the region. 


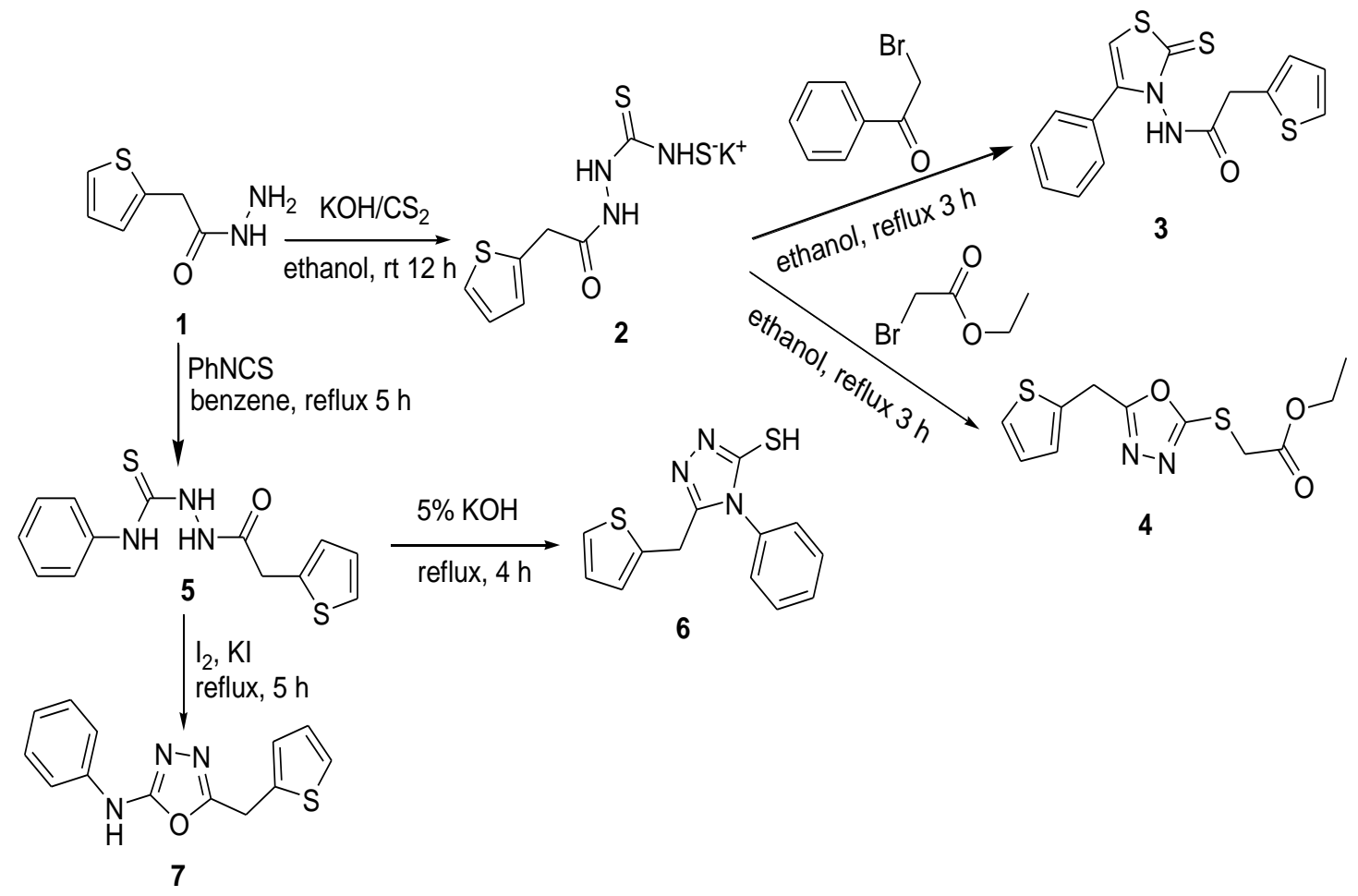

Scheme 1. Synthesis of $3,4,5,6$ and 7

4-phenyl-1-(2-(thiophen-2yl)acetyl)thiosemicarbezide (5) was prepared via reaction of 1 and phenyl isothiocyanate in boiling dry benzene. The IR spectrum of thiosemicarbezide 5 showed 3235 and $3210 \mathrm{~cm}^{-1}$ 1682, $1671 \mathrm{~cm}^{-1}$ corresponding - $\mathrm{NH}$ hydrazide and thioamide carbonyl groups absorption bands, respectively. The ${ }^{1} \mathrm{H}$ NMR spectrum revealed $\delta 9.3 \mathrm{ppm}$ signal (-NH) proton of hydrazide, $3.3 \mathrm{ppm}$ signals $\left(-\mathrm{CH}_{2}\right)$ protons of methylene and $1.9 \mathrm{ppm}$ the signals $(-\mathrm{NH})$ proton of amine in the region. The ${ }^{13} \mathrm{C}$ NMR spectrum revealed $\delta 178.3$ and 167.5 ppm signals (thiocarbonyl and carbonyl of carbohydrazide) in the region and $30.2 \mathrm{ppm}$ signal of methylene carbon in the region. 4phenyl-5-(thiophen-2-ylmethyl)-4H-1,2,4-

triazole-3-thiol (6) was conducted to intramolecular cyclization of compound 5 in boiling potassium hydroxide solution. The IR spectrum of 1,2,4-triazole derivative 6 showed $2668 \mathrm{~cm}^{-1}$ corresponding -SH absorption band. The ${ }^{1} \mathrm{H}$ NMR spectrum revealed $\delta 12.1 \mathrm{ppm}$ signal $-\mathrm{SH}$ proton in the region and $\delta$ 7.1-6.6 ppm multiplied signals $(-\mathrm{CH})$ protons of aromatic ring. The ${ }^{13} \mathrm{C}$ NMR spectrum revealed $\delta 170.5$ and $165.3 \mathrm{ppm}$ signals carbons of (C3) and (C5) of 1,2,4-triazole ring in the region. 1,3,4-oxadiazol-2-amine derivative (7) was conducted to compound 5, potassium iodide and iodine in the presence of sodium hydroxide solution. The IR spectrum of 1,3,4-oxadiazol (7) showed $3235 \mathrm{~cm}^{-1}$ corresponding -NH group and $1610 \mathrm{~cm}^{-1}(\mathrm{C}=\mathrm{N})$ group absorption bands. The ${ }^{1} \mathrm{H}-\mathrm{NMR}$ spectrum revealed $\delta 3.8 \mathrm{ppm}$ signal ($\mathrm{NH}$ ) proton of amine, between $\delta 7.1$ and $6.3 \mathrm{ppm}$ the $(-\mathrm{CH})$ protons of aromatic ring. The ${ }^{13} \mathrm{C}$ NMR spectrum revealed $\delta 164.7$ and $157.2 \mathrm{ppm}$ signals carbons of (C5) and (C2) of 1,2,4triazole ring in the region, respectively.

1-(5-amino-3-hydroxy-1H-pyrazol-1-yl)2(thiophen-2yl)ethanone (8) was obtained resulting intramolecular cyclization ethyl cyanoacetate and compound 1 in boiling ethanol. The IR spectrum of compound 8 showed 3415 $\mathrm{cm}^{-1}$ corresponding $(-\mathrm{OH})$ hydroxyl, $3158 \mathrm{~cm}^{-1}$ $\left(-\mathrm{NH}_{2}\right)$ amine and $1665 \mathrm{~cm}^{-1}(\mathrm{C}=\mathrm{O})$ carbonyl groups, respectively. The ${ }^{1} \mathrm{H}-\mathrm{NMR}$ spectrum revealed $\delta 5.3$ and 3.3 ppm signal $(-\mathrm{OH})$ proton 
and $\left(-\mathrm{NH}_{2}\right)$ protons in the region, respectively. The ${ }^{13} \mathrm{C}$ NMR spectrum revealed $\delta$ 147.1, 144.1 ppm signals carbons of (C3) and (C5) of aromatic ring in the region and $193.0 \mathrm{ppm}$ signal carbonyl group in the region. 1,3,4-oxadiazole derivative (9) was synthesized from heating 1 and benzoic acid in the presence of trifluoro acetic acid. The ${ }^{1} \mathrm{H}$ NMR spectrum revealed $\delta$ 3.3 ppm signals $\left(-\mathrm{CH}_{2}\right)$ protons of methylene and $\delta$ 7.3-6.3 ppm the $(-\mathrm{CH})$ protons of aromatic ring. The ${ }^{13} \mathrm{C}$ NMR spectrum revealed $\delta$ 162.1, 158.6 ppm signals carbons of (C2) and (C5) in the region and $\delta 28.4 \mathrm{ppm}$ signals of methylene carbons, respectively. A series hydrazones 10a-e were synthesized from condensation of compound 1 and aromatic aldehydes (benzaldehyde, 2-hydroxybenzaldeyde, 2hydroxy-5-nitrobenzaldeyde, thiophene-2carbaldehyde, 4-dimethyl amino benzaldehyde) in ethanol in Scheme2.

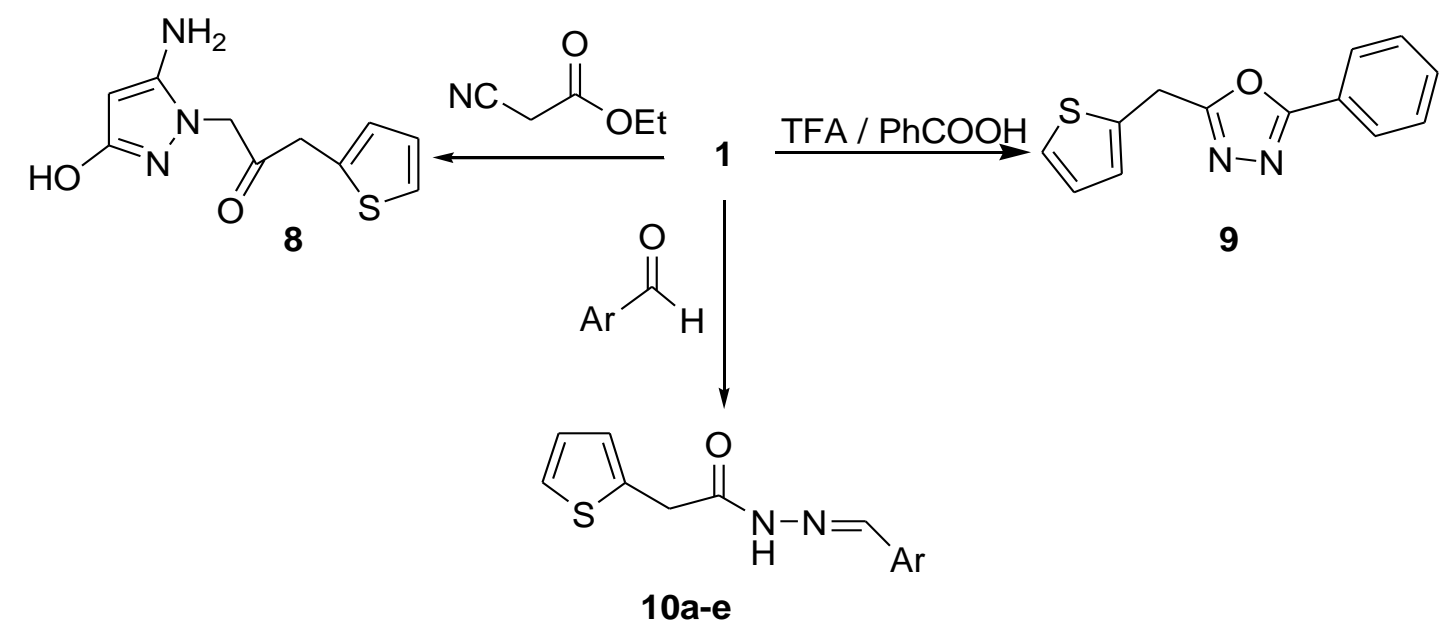<smiles>Cc1ccccc1O</smiles>

Scheme 2. Synthesis of $\mathbf{8 ,} 9$ and 10a-e

The IR spectrum of compounds 10a-e showed corresponding absorption bands between 3345 and $3210 \mathrm{~cm}^{-1}(-\mathrm{NH})$ of hydrazones, besides between 1682 and $1675 \mathrm{~cm}^{-1}$ imine peaks $(\mathrm{C}=\mathrm{N})$. IR spectrum showed 1668, 1664, 1662, 1656 and $1667 \mathrm{~cm}^{-1}(\mathrm{C}=\mathrm{O})$ carbonyl peaks of hydrazones, respectively. The ${ }^{1} \mathrm{H}$ NMR spectrum revealed between $\delta 4.3$ and 2.9 ppm signals
$\left(-\mathrm{CH}_{2}\right)$ protons of methylene, $\delta$ 7.9-6.5 $\mathrm{ppm}$ the $(-\mathrm{CH})$ protons of aromatic ring, around $\delta 8.2$ ppm proton of imine signals $(-\mathrm{N}=\mathrm{CH})$ in the region. 3-oxo-3-phenyl- $N$-(2-(thiophen-2yl)acetyl)propane hydrazide (11) was synthesized by refluxing reaction of compound 1 and ethyl benzoylacetate in Scheme 3. 


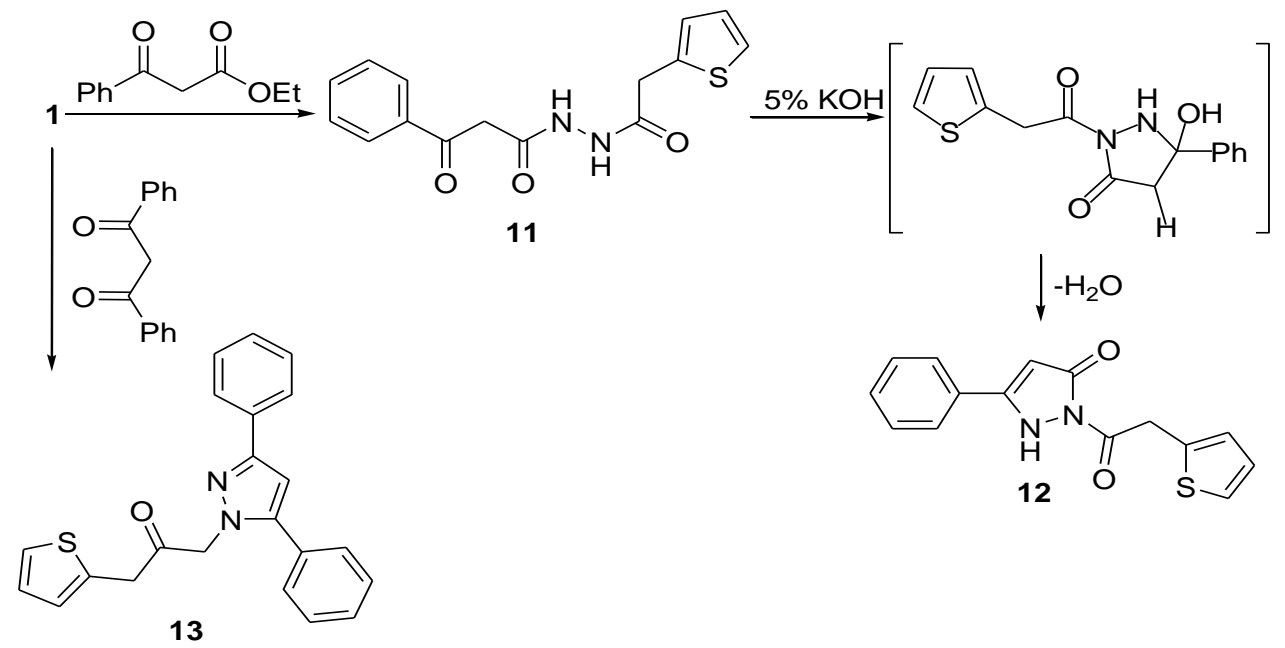

Scheme 3. Synthesis of 11, 12 and 13

IR spectrum of compound 11 showed 3296, $3257 \mathrm{~cm}^{-1}$ absorption bands corresponding ($\mathrm{NH})$ groups and 1668, $1664 \mathrm{~cm}^{-1}(\mathrm{C}=\mathrm{O})$ carbonyls groups, respectively. The ${ }^{1} \mathrm{H}-\mathrm{NMR}$ spectrum revealed $\delta 9.9$ ppm signals $(-\mathrm{NH})$ protons of molecule $\delta 11,3.1 \mathrm{ppm}$ the signals ($\mathrm{CH}_{2}$ ) protons of methylene and $\delta$ 8.7-6.6 ppm the $(-\mathrm{CH})$ protons of aromatic ring. The ${ }^{13} \mathrm{C}$ NMR spectrum revealed $\delta$ 191.3, $164.2 \mathrm{ppm}$ signals carbonyl of groups in the region and $\delta$ 33.09 ppm the signals of methylene carbons, respectively.

3-phenyl-1-(2-(thiophen-2yl) acetyl)-1,2-dihydro pyrazol-5-one (12) was synthesized from cyclization followed its dehydration and intermediate product which occurred by refluxing compound 11 dissolved potassium hydroxide solution. The IR spectrum of compound 12 showed $3254 \mathrm{~cm}^{-1}$ corresponding (-NH) of pyrazole ring absorption bands and $1678 \mathrm{~cm}^{-1}(\mathrm{C}=\mathrm{O})$ carbonyl of pyrazole ring, respectively. The ${ }^{1} \mathrm{H}-\mathrm{NMR}$ spectrum revealed $\delta$ $2.2 \mathrm{ppm}$ signal (-NH) proton of pyrazole, 3.3 ppm signals $\left(-\mathrm{CH}_{2}\right)$ protons of methylene and $\delta$ 8.1-6.3 ppm the (-CH) protons of aromatic ring. The ${ }^{13} \mathrm{C}$ NMR spectrum revealed $\delta 171.3,164.3$ ppm signals carbons of (C3) and (C5) of aromatic ring and $\delta 34.4 \mathrm{ppm}$ the signals of methylene carbons in the region. 2-(3,5diphenyl-1H-pyrazol-1-yl)-1-(thiophen-2- yl)ethanone (13) was synthesized from 1 and 1,3-diphenylpropane-1,3-dione with a catalytic amount of DMF in glacial acid. The IR spectrum of compound 13 showed $1648 \mathrm{~cm}^{-1}$ corresponding $(\mathrm{C}=\mathrm{O})$ absorption band. The ${ }^{1} \mathrm{H}$ NMR spectrum revealed $\delta$ 7.9-6.5 ppm signal ($\mathrm{CH})$ protons of aromatic ring. The ${ }^{13} \mathrm{C} \mathrm{NMR}$ spectrum revealed $\delta 183.4$ ppm signal carbonyl group in the region.

\section{CONCLUSION}

The application areas of thiophene-derived polymers are now considerably increased. The areas of their use vary considerably. As we mentioned above, the mostly using area is medicine, agriculture and food industry. Besides, it is known that these compounds have a potential to be used in dye, electronic and optoelectrochromic devices, biodiagnostics and conductivity-based sensor devices too (Roncali, 1992; Kuila and Nandy, 2006; Mortaheb et al., 2012). As it is seen these derives should have different features. All of the synthesized compounds were structurally characterized. Furthermore, new synthesized compounds were carried out against important pathogenic microorganisms. The samples (3-9, 10a-e, 1113) were separately tested against Bacillus subtilis ATCC 6633 and Staphylococcus aureus 6538 as examples of Gram-positive bacteria, 
Enterobacter aerogenes ATCC 13048 and Escherichia coli as examples of Gram-negative bacteria (Ren et al., 2002). The present results indicated that these compounds were not showed antibacterial activity. The further studies must be done for the electronic, opto-electrochromic or bio diagnostics features.

\section{REFERENCES}

Andersson CD, Karlberg T, Ekblad T, Lindgren AE, Thorsell AG, Spjut S, Elofsson M, 2012. Discovery of ligands for ADP-ribosyltransferases via docking-based virtual screening. Journal Medicinal Chemistry 55:17 7706-7718.

Christophe M, Sylvain G, Christian L, Maria RP, Frederic F, Cyril I, Michel B, 2011. Synthesis and biological activities of triazole derivatives as inhibitors of InhA and antituberculosis agents. European Journal of Medicinal Chemistry 46:11 5524-5531.

Fakhr IMI, Radwan MAAS. El-Batran O, Abd El-Salam ME, El-Shenawy SM, 2009. Synthesis and pharmacological evaluation of 2-substituted benzo [b] thiophenes as anti-inflammatory and analgesic agents. European Journal of Medicinal Chemistry 44:4 17181725.

Gouda MA, Berghot MA, El-Ghani GEA, Khalil AM, 2010. Synthesis and antimicrobial activities of some new thiazole and pyrazole derivatives based on 4,5,6,7tetrahydrobenzothiophene moiety. European Journal of Medicinal Chemistry 45:4 1338-1345.

Isloor M, Kalluraya B, Pai KS, 2010. Synthesis, characterization and biological activities of some new benzo [b] thiophene derivatives. European Journal of Medicinal Chemistry 45:2 825-830.

Kuila BK, Nandi AK, 2006. Structural Hierarchy in MeltProcessed Poly (3-hexyl thiophene)- Montmorillonite Clay Nanocomposites: Novel Physical, Mechanical, Optical, and Conductivity Properties. The Journal of Physical Chemistry B 110:4 1621-1631.

Maddila S, Pagadala R, Jonnalagadda S, 2013. 1,2,4triazoles: a review of synthetic approaches and the biological activity. Letters in Organic Chemistry 10:10 693-714.

Meltzer RJ, Lewis AD, McMillan FH, Genzer JD, Leonard F, King JA, 1953. Antitubercular substances. III. Nonpyridinoid heterocyclic hydrazides. Journal of the American Pharmacists Association 42: 594-600.

Moghaddam FM, Boinee HZ, 2004. An efficient and facile one-step synthesis of highly substituted thiophenes. Tetrahedron 60:29 6085-6089.
Mortaheb HR, Ghaemmaghami F, Mokhtarani B, 2012. A review on removal of sulfur components from gasoline by pervaporation. Chemical Engineering Research and Design 90:3 409-432.

Naresh P, Pattanaik P, Priyadarshini RL, Reddy DR, 2013. Synthetic characterization antimicrobial screening of some novel 6-fluorobenzothiazole substituted [1,2,4] triazole analogues. International Journal of Pharmacy and Pharmaceutical Sciences 1: 18-24.

Parai MK, Panda G, Chaturvedi V, Manju YK, Sinha S. 2008. Thiophene containing triarylmethanes as antitubercular agents. Bioorganic Medicinal Chemistry Letters 18 (1): 289-292.

Patel R, Kumari P, Chikhalia K, 2013. New quinolinyl-1, 3,4-oxadiazoles: Synthesis, in vitro antibacterial, antifungal and antituberculosis studies. Medicinal Chemistry 9:4 596-607.

Pinto E, Queiroz MRP. Vale-Silva LA, Oliveira JF, Begouin A, Begouin JM, Kirsch G, 2008. Antifungal activity of synthetic di (hetero) arylamines based on the benzo [b] thiophene moiety. Bioorganic Medicinal Chemistry 16:17 8172-8177.

Ramazani A, Rezaei A, 2010. Novel one-pot, fourcomponent condensation reaction: An efficient approach for the synthesis of 2, 5-disubstituted 1, 3, 4oxadiazole derivatives by a Ugi-4CR/aza-wittig sequence. Organic Letter 12:12 2852-2855.

Roncali J, 1992. Conjugated poly (thiophenes): synthesis, functionalization, and applications. Chemical Reviews 92:4 711-738.

Ren S, Wang R, Komatsu K, Bonaz-Krause P, Zyrianov Y, McKenna CE, Csipke C, Tokes ZA, Lien EJ, 2002. Synthesis, biological evaluation, and quantitative structure-activity relationship analysis of new Schiff bases of hydroxysemicarbazide as potential antitumor agents. Journal of Medicinal Chemistry 45:2 410-419.

Sagardoy AA, Gil MJ, Villar R, Viñas M, Arrazola A, Encío I, Martinez-Merino V, 2010. Benzo [b] thiophene-6-carboxamide 1, 1-dioxides: Inhibitors of human cancer cell growth at nanomolar concentrations. Bioorganic Medicinal Chemistry 18:15 5701-5706.

Zarudnitskii EV, Pervak II, Merkulov AS, Yurchenko AA, Tolmachev AA, 2008.Trimethylsilyl-1, 3, 4oxadiazoles-new useful synthons for the synthesis of various 2, 5-disubstituted-1, 3, 4-oxadiazoles. Tetrahedron 64:45 10431-10442.

William OF, Principles of Medicinal Chemistry, 3rd ed. Lippincott Williams Wilkins Publication, Philadelphia, USA, p. 6511989.

Zhang L, Zhang A, Chen X, Lei X, Nan X, Chen D, Zhang Z, 2002. Synthesis and Biological Activity of 3-(2Furanyl)-6-Aryl-1, 2, 4-Triazolo [3,4-b]-1,3,4Thiadiazoles. Molecules 7: 681-689. 